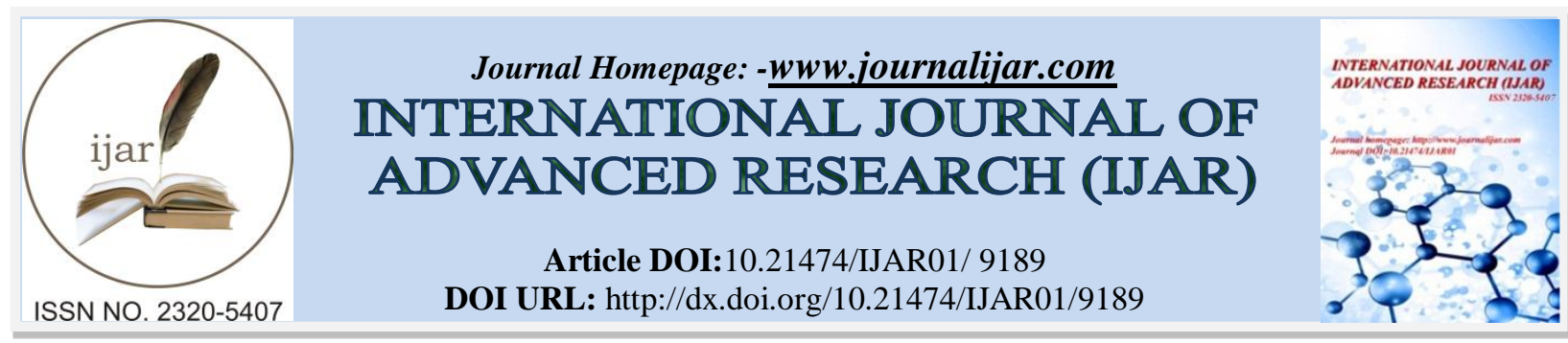

RESEARCH ARTICLE

\title{
A REVIEW STYDY ON LIFESTYLE DISEASES AND ITS AYURVEDIC PREVENTION
}

\section{Dr. Jamuna Uranw ${ }^{1}$, Dr.Gitanjali ${ }^{2}$ Sasmal and Dr.Vinay Bhardwaj ${ }^{3}$.}

1. M.D. Scholar, P.G. department of kriya sharir,govt. Ayurvedic college, raipur (c.g.).

2. H.O.D. \& Reader, P.G. department of kriya sharir,govt. Ayurvedic college, raipur (c.g.).

3. Lecturer.P.G. department of kriya sharir,govt. Ayurvedic college, raipur (c.g.).

\section{Manuscript Info}

Manuscript History

Received: 02 April 2019

Final Accepted: 04 May 2019

Published: June 2019

Key words:-

Lifestyle disorder, Prevention and Rasayannas.

\begin{abstract}
Lifestyle disorders is an umbrella term given to all the diseases which arise because of unhealthy lifestyle. Lifestyle diseases are the outcome of the way we leads our lives and diseases can be barred and their influence weakened with lifestyle modulation, improving diet and making host-environment interaction healthier. The most common lifestyle diseases include Hypertension, Diabetes, Arthritis, Obesity, Insomnia etc which are the major cause of mortality in today's world. Not only are these lifestyle diseases thwarting, but these are also interfering with natural comfort of wellbeing.

Ayurveda knowledge system that imbibes what are the dynamic of life; what is beneficial for life and what is detrimental for life; what is happy life; and what is unhappy life in physical, psychological, social and spiritual terms. In the management of lifestyle diseases, Ayurveda offers various regimens including Ahara and Vihar (dietary habits and daily routine). Dinacharya (daily regimen), Ritucharya (seasonal regimen), Panchkarma (five detoxification and bio-purification therapies), and Rasayana (rejuvenation) therapies. The Sadvritta (ideal routines) and Aachara Rasayana (code of conduct) are utmost important to maintain a healthy and happy psychological perspective.
\end{abstract}

Copy Right, IJAR, 2019,. All rights reserved.

\section{Introduction:-}

Lifestyle disorder is an umbrella term given to all the disease which arise because of unhealthy lifestyle. The most common Lifestyle diseases include Hypertension, Diabetes, Arthritis, Obesity, Insomnia etc which are the major cause of mortality in today's world. Not only are these lifestyle diseases thwarting, but these are also interfering with natural comfort of wellbeing Lifestyle disorders were more common in western world but the scenario has changed dramatically.

As Ayurveda is recognized as premost life science and described ways to prevent and manage lifestyle disorders; the world is being attracted towards its potential. Ayurveda provides better solution in the forms of proper dietary management, lifestyle advises, Panchkarma like detoxification and bio-purification procedures, medicaments and rejuvenation therapies. The holistics approach of Ayurveda treating the patient as a whole, meaning intervention targeted towards complete physical, psychological, and spiritual well-being makes this science a wonderful option in lifestyle disorder.

Corresponding Author:- Jamuna Uranw.

Address:-M.D. Scholar, P.G. department of kriya sharir,govt. Ayurvedic college, raipur (c.g.). 
Ayurveda-Knowledge system that imbibes what are the dynamics of life; what is happy life; and what is happy life; and what is unhappy life in physical, psychological, social and spiritual terms. Underlines the importance of lifecycle approach on the basis of health and disease determinants.

\section{Aim And Objectives:-}

1. Health education and Disease.

2. Lifestyle disorder and their problems.

3. Prevention through Ayurveda.

\section{Material And Methods:-}

1. Literatures of Ayurveda text books.

2. Modern texts books and net surfing.

3. Research papers and articals from journals.

\section{Health is Balance in System Biology:-}

"Dosha-Dhatu-Mala Moolam hi Shariram."

1. Dosha- Physiological entities.

2. Dhatu- Structural entities.

3. Mala- Excretory entities.

\section{Who is Healthy:-}

A person in sustainable equilibrium with-

1. Balanced humoral functions.

2. Balanced bio-fire i.e, enzymatic functions.

3. Balanced tissue/metabolic functions.

4. Happiness of soul, sense organs and mind.

\section{Lifestyle: Ayurveda way:}

Lifestyle- According to ayurveda-

1. Dincharya

2. Ratricharya

3. Ritucharya

4. Sadvritta

Vyayam (traiupstambh)-

1. Aahar

2. Nidra

3. Brahmacharya

\section{Compnents of Lifestyle-}

1. Aahaar (food)

2. Vihaar (Behaviour)

3. Aachaar (conduct)

4.Vichaar (Thinking)

\section{Attributes of Healthy Living :-}

1. H-Holistic and wholes food.

2. E- Eating habits.

3. A-Appropriate lifestyle as per Prakriti.

4. L- Living with disciplined behavior.

5. T- Tranquility in life: Manoshanti.

6. H- Harmonious interaction.

7. Y-Yes-attitute, yearly assessment.

\section{Causes:-}

The commonest cause of lifestyle disorders are eating unhealthy foods, over eating, over dependence on processed 
foods, energy drinks, artificial sweetners and fast foods. Sedentary living, smoking, drinking alcohol, stress, poor sleeping habits which are all attributed mainly to the so called modern living habits makes the situation worse. There is yet another important problem of the modern world. That is poor exposure to sunlight and fresh air. Diet and lifestyle are major factors thought to influence susceptibility to lifestyle diseases. The nature and duration of work the amount of time you spend with your loved ones, the stress factors, your physical activity etc decide decide on how soon you are likely to land up in any one of the lifestyle disorders. More work and no play, makes a lot of us prone to a host of diseases. Along with that there are certain other factor such as heredity, age and gender which cannot be avoided or controlled. But the other factors that can be avoided or controlled are drug abuse, tobaccosmoking and alcohol drinking.

\section{Incidence:-}

With increasing prevalence of lifestyle diseases in India, one out of four Indians is at risk of dying from noncommunicable diseases like diabetes, cardio-vascular ailments or cancer before the age of of 70, according to estimates of various global and domestic organisation. According to the NCD (Noncommunicable Disease) country profiles of 2014 released by WHO, diseases like cancer, chronic respiratory problems and cardiovascular diseases are the biggest global killers accounting for 38 millions death every year with a whopping 28 million in low and middle income countries, including India, As per WHO estimates, NCDs account for almost $60 \%$ of the total mortality reported annually in India.

\section{Life Style Diseases:-}

\section{Critical Age for lifestyle Disease-}

The most important period in life is between 40 to 50 years of age, when the impact of one's lifestyle is visible and manifested as disease, Why?

System biology gradually gets deranged with the input of disease determinants causing sustained imbalance in metabolic modalities.

Basis of imbalance is excessive and continuous exposure to lifestyle factor in contravention of Prakriti characteristics.

\section{Dilemma with Lifestyle Diseases:-}

1. Insidious onset.

2. Longer span to become cause of death.

3. Medicines not the effective answer.

4. Not easy to manage, forget about cure.

5. Enough money required to tackle Lds.

Characteristics of Ayurveda Approach:-Customized stragies based on-

1. Prevention of causative \& precipitating factors.

2. Bio-purification- Panchkarma.

3. Palliative treatment.

4. Lifestyle intervention.

5. Rejuvenation therapies.

6. Restoration of systemic functioning and psychophysical well being.

7. Holistic treatment is designed to achieve homeostasis (equilibrium of milieu interior) rather than to counter the symptoms only.

\section{Treatment Approach Of Ayurveda:-}

1. Avoidance of disease factors.

2. Bio-purification.

3. Palliative treatment.

4. Holistic \& wholesome lifestyle.

\section{OBJECTIVES OF TREATMENT:-}

1. To identify causative and aggravating factors of disease and check them.

2. To provide symptomatic relief.

3. To resolve disease process and prevent its progression.

4. To prevent reccurrence and complications. 
5. To restore normal life, psycho-physical capacity.

Why ayurveda?

1. Conventional medicine doesnot have answers to all health care needs, particularly multidemensional lifestyle diseases.

2. Ayurveda offers more personalized care and customized treatment options.

\section{Prevention Through Ayurveda-}

In the management of lifestyle diseases, Ayurveda offers various regimens including Ahara and Vihar ( dietary habits \& daily routine). Dincharya (daily regimen), Panchkarma ( five detoxification and bio-purification therapies), and Rasayana ( rejuvenation) therapies. The Sadvritta (ideal routine) and Aachar Rasayana (code of conduct ) are utmost important to maintain a healthy and happy psychological perspective.

\section{Aahara:-}

Aahara and Vihara play a central role in the life according to Ayurvedic understanding. Ayurveda places special emphasizes on Aahara \& Vihar to as measures for better living, health and wellness. Ayurveda emphasizes more on Aahara in comparison to other systems of medicines and also explored its emotional and spiritual significance, in addition to its material and biological attributes. Aahara is considered as Prana ( basis of life) in Ayurveda. Aahara has described as one of the Trayopastambha (celibacy). Diet is considered as vital for a human body as it provides the basic nutrients and promotes longevity. Ayurveda always emphasizes on consuming healthy and nutritious diet for maintaining good health. As per the view point of Ayurveda, both the living human body and the diseases afflicting it are it are the product of Aahara. Use of hita-ahara (wholesome diet) promotes health and longevity and ahita-aahara (unwholesome diet) promotes manifestation of different disorders. Unfortunately in modern era the concept of hita-ahara is continuously being ignored leading to the emergence of lifestyle disorders. Ayurveda also described eighteen types of dietary incompatibilities (Viruddha Ahara), which should be avoided to maintain health and longevity. In this way Ayurveda offer different Pathayapathya (do's \& don'ts) regarding diet/dietary supplementations which definitely help in the prevention and management of a wide range of lifestyle disorders.

\section{Daivavyapashraya Chikitsa:-}

Daivavyapashraya Chikitsa includes chanting Mantras, Aushadhi and Mani Dharana (spiritual use of herbs and gems) Mangal Karma (propitiatory), Bali (offering oblations), Homa, Prayashchita (ceremonial penances), Upavasa (fasting), Swastyayana (rituals for social well being) etc. Some $90 \%$ of the world's population engaged in religious or spiritual practices. These practices are major means of coping with stress and for prevention and management of lifestyle disorders.

\section{Satvavajaya Chikitsa:-}

The author of foremost classic on internal medicine, Charaka Samhita defines it as a method of restraining the mind from desire for unwholesome objects. All these measures help in developing control over the Manas or mind, which is usually unstable.

\section{Dincharya:-}

Normal circadian rhythms are very important in day life to maintain biological clock. Ayurveda suggests to begin daily habits with awareness, early rising, avoid suppression of natural urges and eliminate wastes as per urge, keep the teeth \& skin cleaned, regular use of massage (Abhyanga), regular daily bathing (bathing enhances the appetite and promotes longevity), consume suitable and wholesome diet according to the appetite and metabolic needs, since it is the basis of life and important for day to day promotion of health. Ayurveda has also suggested avoiding late night sleep, eating state foods, having sex with inappropriate partner \& at unsuitable time and position and the misuse of senses. These might lead to imbalance in the circadian rhythms and thus long term imbalance predisposes to lifestyle disorders. Therefore, one has to stay aware about this daily regimen for day to day promotion of health, boost immunity and prevention from lifestyle disorders.

\section{Ritucharya:-}

Ritu (season) classified by different features expresses different effects on the body as well as on the environment. Ayurveda has depicted various rules and regimens, regarding diet and lifestyle to acclimatize seasonal enforcement easily without altering body homeostasis. The prime objective of Ayurvedic system of medicine is preventive aspect, which can be achieved by the modification in diet and lifestyle in response to change in climatic condition. 
Ritucharya represents a very important aspect of preventive aspect, which can be achieved by the modification in diet and lifestyle in response to change in climatic condition. Ritucharya represents a very important aspect of preventive measure for various illnesses including lifestyle disorders as mentioned in Ayurvedic texts. It is the only system of medicine in the world which proposes the need of regular purification of the human biological system from level to the molecular level to render it suitable for self recovery and rejuvenated regularly. Therefore, Ayurveda advises seasonal Panchakarma as preventive measures for maintenance and promotion of physical as well as mental health.

\section{Panchakarma:-}

Panchakarma is a collective term used to address the five principal procedures or technologies of bio-purification. These procedures are used in order to cleanse the body channels, to eliminate toxins out of the body, brings about the harmony of bio-humour (Tridosha i.e, Vata, Pitta, Kapha, and Manasa Dosha i.e, Raja and Tama) to obtain longlasting beneficial effects which further leads to chemical balance inside the bio-system and thus provide the normal chemical and electrical environment in brain and ultimately restore the homeostasis. When done properly, these promote psychosomatic health, rejuvenate the body and increase the receptivity and effectiveness of Panchakarma include Vaman (therapeutic emesis), Virechan (therapeutics purgation), Asthapan Basti ( therapeutics decoction enema), Anuvasana Basti (therapeutics oil enema) and Nasya Karma ( nasal medication).

Ayurveda emphasizes more on the preventive aspect of the Panchakarma also restore the mental health, reduces the stress and therefore, help in the prevention as well as management of many lifestyle disorders. Panchakarma is claimed for its preventive, promotive, prophylactic and rejuvenative properties Rasayana. In addition to food and diet, Ayurveda propounds a seperate concept of medicinal dietary supplements in the contexts of Rasayana ( rejuvenative measures).

Rasayanas can be used as nutritional supplements as well as medicine depending upon its various types. Most Rasayanas produce their nourishing and rejuvenating effect by promoting the Agni bala, acting as direct nutrients and by way of Sroto-prasadan (purification of body channels), resulting in an improved nutritional status which further leads to an improved quality of Dhatus or body tissues. Although the Rasayanas are a generic class of restorative and rejuvenative supplements, many Rasayanas could be tissue and organ specific such as Medhya Rasayana for the brain, Hridya Rasayana for the heart, Twachya Rasayana for the skin and so on. Various studies on Rasayana drugs suggest their following action.

1. Immunomodulator.

2. Adaptogenic.

3. Antioxident.

4. Nootropic.

5. Antistress.

\section{Sadvritta and Achara Rasayana:-}

Ayurveda offers some code of good conducts under the heading of Sadvritta and Achara Rasayana can be categarizes into personal (viz. Limited sexual relations, early sleeping and awakening, avoid excess exertion, avoid suppression of natural urges, regime of bathing, keeping skin clean), social (keep mercy on others, telling truth, avoid alcoholism, be soft hearted, always use cleaned and washed cloths), psychological and emotional ( try to be in a steady mental state i.e, avoid to memorize if being insulted by anyone, keep patience, etc ). Such type of lifestyle adaptation always helpful in the prevention and management of a wide range of lifestyle disorder.

Hence, Ayurveda has an upper edge in treating the disease with emphasis on its root cause. The Ayurvedic physician concentrates on achieving the objective of Ayurveda for promotion of health, prevention and management of disease for a healthy and happy life in the ailing society.

\section{Conclusion:-}

"Lifestyle diseases" known internationally as 'non-communicable disease' (NCD's) or 'chronic diseases of lifestyle' (CDL) emerge from inappropriate relationship of people with their environment.These are a group of diseases that share similar risk factors, which may be due to exposure over many decades, unhealthy diets, smoking, lack of exercise, and stress. 
The major risk factors are high blood pressure, tobacco addiction, high blood cholesterol, diabetes and obesity.These result in various longterm disease processes, culminating in high mortality rates attributable to stroke, heart attack, tobacco-and nutrition-induced cancers, chronic bronchitis, emphysema, renal failure, and many others.

From the history of treatment and preventive measures given to the persons suffering from lifestyle diseases, Ayurveda has proven its role and importance in this area. The other systems do not have any other answers than the supply of nutritional food and physical activities in this respect.

\section{References:-}

1. Charaka (2003), Charak Samhita Vol I ,By R.K Sharma, Bhagavan Dash-2 ${ }^{\text {nd }}$ Edition, Choukhambha Sanskrit Series Office, Varanasi.

2. Vaagbhata (2000), Vagbhata's Ashtanga Hridaya-English Translation by Prof. K.R. Srikantaha Murthy-Vol I, $3^{\text {rd }}$ Edition, Krishnads Academy, Varanasi, Sutra sthana.

3. Rajeshwar data shashtri e.t al., editors. Charak Samhita, Varanasi: Chaukambha Bhaarti Academy;2005.

4. Singh Satyapal, Tripathi JS, Rai NP, An Integrated Dietary Approach for the Management of Dermatological Disorders.

5. Rajeshwar data shashtri e.t al., editors, Charak Samhita Varanasi: Chaukhambha Bhaarti Academy;2005.

6. Singh Satyapal, Role of Vihara (Ayurvedic Lifestyle) in the Prevention and Management of Dermatological Disorders. Int J Pharm Bio Sci, 2015:6(4): (B) 366-371.

7. Thakkar Jayesh, Chaudhari S, Sarka Prasanta K. Ritucharya :Answer to the lifestyle disorders. AYU , 2011; 32 (4):466-471.

8. Rajeshwar datta shastri e.t al., editors. Charak Samhita. Varanasi : Chaukhambha Bhaarti Academy;2005.

9. Singh Satyapal, Tripathi JS, Rai NP. An overview of Ayurvedic \& contemporary approaches to Psychodermatology. JPHYTO, 2014;3(4):286-299.

10. Vithalani LV. Mental Health and its Preventive Aspects through A yurveda and Yoga. Asian Journals of Modern Ayurvedic Medical Science, 2012;1(1); 1-9.

11. http://naturalheathperspective.com/home/civilization.html.

12. http://www.ayuinus.com/ayurveda -yoga-hope-lifestyle-disease.

13. http://rohiniwithfindia.indiatimes.com/2012/06/02/scope-of-ayurveda-in-life-style-diseases/.

14. Singh R.H The Basic Tenets of Ayurvedic Dietetics and Nutrition. In:S Rastogi, editors.Ayurvedic Science of Food and Nutrition, part-1. $1^{\text {st }}$ ed. New York: Springer; 2014.p 15-23. 